\title{
E-Reading Vs Traditional Reading: Can Internet, Social media and Gadgets Bridge the Gap between Reading and Learning among Medical Students?
}

\author{
Forman Erwin Siagian, ${ }^{*}$ Esy Maryanti, ${ }^{2}$
}

\begin{abstract}
ABSTRAK
Membaca menjadi dasar dalam belajar dan dengan perkembangan teknologi komunikasi informasi (TIK), membaca secara modern sekarang ini menjadi pengalaman yang lebih menarik dibanding sebelumnya ( misalnya membaca secara tradisional); akibat ketersediaan bahan bacaan elektronik di internet. Meski terdapat potensi efek yang tidak diinginkan, hampir tidak mungkin membatasi penetrasi TIK dalam hidup keseharian kita. Pilihannya lebih kepada kendali atas efek yang tidak dibutuhkan dan disisi lain memaksimalisasi potensi e-reading di internet untuk keuntungan pembaca.
\end{abstract}

Kata kunci: literatur, interaktif, user-friendly, telepon selular, modern

Reading is one of main activity used for learning, especially for those in higher education like medical students. ${ }^{1-4}$ People read books in order to gain knowledge, and to some extent, for some people, the textbook is central for reading while to some other it might only supplementary and acts as a guide or introduction among the topics covered. ${ }^{3}$ Whatever role the school/faculty/institution chooses for the textbook to play in the educational purpose, all of the teachers/lecturers and even students are all agree that the textbook still an important and essential learning tool. ${ }^{2-4}$

In this digital age, the nature of the textbook is changing. ${ }^{5}$ Nowadays, reading activity become more fun and easier because it can be done electronically (e-reading).$^{3-5}$ E-reading offers advantage to their readers but in the same time also disadvantage, compare to traditional reading (reading printed materials, e.g book or paper) ${ }^{1,2}$ Internet, Social media, and or, electronic books (e-books) are good example of how is improvement and advancement on information and communication technologies (ICT) has reached the condition where it touched

\footnotetext{
* Corresponding author : Email: formanerwin@yahoo.com

1 Department of Parasitology-Universitas Kristen Indonesia, Jakarta-Indonesia,

2 Department of Parasitology-Universitas Riau,
}

and affected every aspect of our life. ${ }^{1-3,5}$ Everything goes or become digital/electronic, the tagline "digitally yours" confirmed the shift on how we live our life, including on reading and learning. ${ }^{3}$ These two, reading and learning, are the main activity of all students, including medical students. ${ }^{1,2}$

In the context of reading and learning, ICT through search engines/internet offers very rapid access to any information wanted/needed, and it can be done through a personal electronic device (personalized features); and it also permits any information to be able to be shared publicly through social media with almost no boundaries (connectedness). ${ }^{4-6}$ This openness and easy access of internet with personalized feature spoiled their users, not to mention other helping features of search engine in the internet also available (e.g for screening of the reading materials needed, it can be done based on topics, language, year of publication etc). ${ }^{1-4}$ This is the reason why internet become so popular.

Number of e-books or scientific papers in the internet is so huge and it continously expanding from time to time. ${ }^{6}$ From the perspective of authorsscientists, publishing their paper/books electronically or in the internet gave them more option and opportunity to reach their readers in wider scope; and that is why the number of good scientific article 
or e-books available for free in the internet continouosly expanding and personal electronic devices or gadgets such as mobile phone, tablets or even laptop that connected to the internet facilitate their owner/reader to pin-point any potential reading material they want. ${ }^{5,6}$ Gadget like kindle also become example of how easy reading in this digital age. ${ }^{6}$ This ICT (e.g internet, social media, e-books) make accessing relevant literature easier and quicker. ${ }^{4,5,7}$ ICT also offer interactivity, a word according to Google dictionary refer to "the ability of a computer to respond to a user's input". ${ }^{5}$

Along those long lists of benefits of e-reading can offer, there are probably some un-wanted effect of this e-reading; concern about authenthicity, including the content, authorships and also to direct and indirect adverse physical effect of their reader, e.g vision, focusing atc. While this increasing in the availability of good reading materials in the internet has seemingly made student's task of literature searching very easy, even too easy, so that it start raising concern among teachers/lecturers about how this ICT might affect the students's methods of reading and learning, and in the end is also the result of their learning to their body of knowledge. ${ }^{7-9} \mathrm{We}$ would like to revealed how is reading and learning among medical students in the era of ICT.

\section{READING AND LEARNING AMONG MEDICAL STUDENT IN THE ERA OF ICT}

One of the ultimate aim of all kind of learning, from the student's perspective, should be to improve their understanding by getting sufficient knowledge from what they read. ${ }^{7-9}$ Huge and massive information available for free in the internet; but effective translation of evidence that was written in reading materials (e.g books or scientific articles) must be transformed into student's body of knowledge by reading and learning carefully and perhaps also repeatedly over and over again, until the reader achieve the important massage from their reading materials. ${ }^{7,8,10,11}$ This is a pre-condition for the students in order to achieve their learning goals/ outcome through their active reading/learning activity. ${ }^{8,10-12}$ The result that the students might achieved depend on how their methods on reading/ learning and what material they use, but reading is still believed to be the best activity to learn something, especially in Medicine. ${ }^{11-14}$ Medical students must read so many textbooks, lecture notes and biomedic papers during their during their education, and this activity is so demanding for them. During their educational process, medical students usually developed their own sytle of reading and learning inorder to adress those issue (pile of textbooks/ papers/lecture notes they must read). Those style of reading and learning also supported by advancement of ICT. ${ }^{1,3,4}$

In this era of ICT, methods of reading and learning also affected and even shifted due to the advancement of ICT tools, e.g internet. ${ }^{15-17}$ Because almost everything available in the internet for free, method of learning has also changed, from reading printed materials on paper (traditional method) to staring down at monitor of their gadget or computer, reading what they want to read electronically (modern method). ${ }^{4}$ But, this shifted brings consequences to their users. ${ }^{17-19}$

Perhaps there is some clear difference on that two (traditional vs modern method); when someone read traditionally, he/she use more of his/her five sense (e.g at least visual and tactile) while on contrary, when someone read electronically, he/she only uses his eyes as the active sensory perception. ${ }^{2-}$ 4,11,12 Many previous study showed us that the more sensory organ uses in coordination during activelearning activity will affect the outcome of study, or at least to the addition of their body of knowledge. ${ }^{9-}$

${ }^{12}$ The more sensory organ used while reading or learning, the deeper the perceptual learning took place, and according to Proulx et al, ${ }^{10}$ perceptual learning driven by multisensory involvement shown us about the complex mechanisms of neuroplasticity, brain organization and resulting functional neuroanatomy.

On contrary, gadget has another feature that can spoil their user, named multi-tasking. ${ }^{5}$ This multitasking ability is a popular activity of this generation of internet. ${ }^{13,14}$ Someone can read something electronically, but at the same time, he/she can also listen to his/her favourite songs that played along with his/her reading activity. At the moment, assumption being made that these ICT might enhance and improve productivity, but on contrary, it can also caused negative effect. ${ }^{12-14,17-19}$ Because of this multi-tasking feature of electronic devices/ 
gadget, it will surely change their user's idea or even their act on doing things. ${ }^{14,18}$ Doing multiple activity at the same time might distract their focus and attention. ${ }^{15,16}$

\section{The truth about Multitasking}

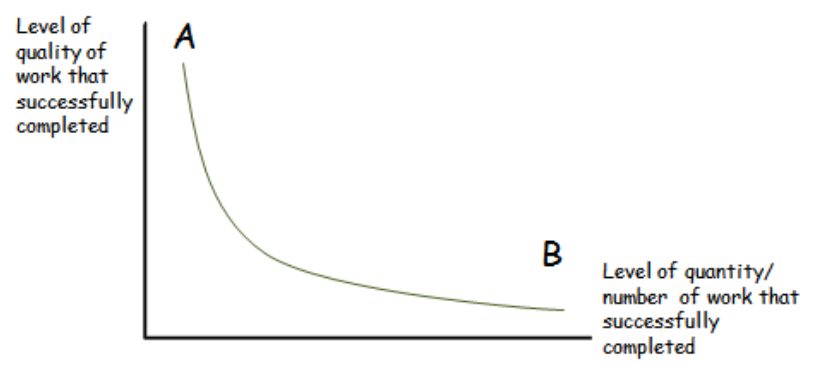

$A=$ simple in appearance, but more productive in result $\mathrm{B}=$ looks complicated, but actually less productive, in quality and perhaps also quantitatively

Figure 1. a graphic about multi-tasking

Actually in the real world, if somebody try to accomplish more than one tasks at the same time or alternating rapidly in between them, many neuroscientists told us that potency of error increased and chronologically it always takes more time- it might often double the time or more- in order to finish the jobs compare to if they were done sequentially. ${ }^{13}$ Electronic multi-tasking ability done by gadget then translated/practiced on to real life by its users on their routine daily activity, e.g individual multi-tasking done by human; but we must remember human is not the same as ICT machine or gadget. ${ }^{5,14}$

Nowadays, for the youth of millennial era, it is a custom or habbit to do several activity at the same time (multi-tasking activity), e.g texting/chatting in social media while driving is a dangerous example. ${ }^{13,14}$ Many study showed us that the practice of multi-tasking actually greatly reduced efficiency. ${ }^{13}$ The habbit of multi-tasking would also probable make the subject become more and more impatient when several things/activity had to be done in succession instead of simultaneously. ${ }^{14,18}$ This shifted insensibly might also have affected the result of learning, as discussed below. ${ }^{5,12,13,14}$

\section{TRADITIONAL VS MODERN READING METHODS: GAP BETWEEN READING AND LEARNING}

Reading as an activity is still the same, but what make the difference is what material you read about, how you read it and also the goal of your reading, because it will surely affect your method of reading and of course in the end will determine the result of your reading and learning. ${ }^{1-3,8}$

With the advancement of technologies, readers nowadays have more options to accomplish their reading activity. ${ }^{1,3,4}$ Millions of reading materials (e.g e-book, scientific paper etc) available for free electronically in the internet, and not to mention yet any gadged that support e-reading like kindle. ${ }^{3}$ The Internet plays a major role in the lives of young people today. ${ }^{1,5}$ Children and youth of the millenial generation engage in online activities in almost all of their time. ${ }^{7}$ During their school time, formally, they used the internet for searching for information and even when completing tasks from their teacher/ lecture or when completing filling their exam. But informally, in their own spare time at home or else, they might use the internet to looking for information they want to know, chat with their friends, engaged in online computer games and are even involved in fan fiction activity, e.g using published material to create pictures and films etc and upload it to a social media platform like path or line. There is a big difference between reading printed materials/ traditional reading and reading electronically/modern reading. ${ }^{2-4}$

Reading printed materials (e.g books) 'forced' the reader to read the whole materials if they wanted to get the full perspective and understanding (and they might have to repeat it several times) before they come into firm conclusion or get the whole idea about what was written by the author correctly. ${ }^{3,4}$ The reader must be very focus to what they read (material-centris) and once again, reading the whole text completely is a must in order to achieve a better understanding on what they read. This activity is surely time- and also energy-consuming, and not to mention is too demanding because it need certain supporting condition e.g quiet room, comfortable place with sufficient light, etc. But the result of learning by reading a printed material like text-book usually 'goes deeper to the heart' in order to built a 
better understanding. Text books, especially those who already printed in several volume, usually contain hard-proof of scientific evidence; firm material that is nice to read in order to make a better understanding. ${ }^{8,9}$ But difficulties with printed materials like books, there is always a circumstances where the access and availability to certain books are limited. ${ }^{2}$ Even in a big library with huge number of collection, there is still many book not available. This limitation is one of the disadvantages of reading printed materials. While on contrary, reading electronically offer limitless access to reading materials. ${ }^{6,16,18}$

Unfortunately, in many respects, nowadays that for the millennial youth, reading a huge amount of definitive, large-scale serious medical text books (traditional learning method) is time consuming and boring for some individuals, especially for those who do not know what they are reading or at least do not realize the importance of prudent reading. ${ }^{12,13,15}$ These two then soon become the gap in reading and learning, between what was wanted and what is found. ${ }^{8}$ A survey on medical students attitudes toward e-books in general that was conducted by Aronsen and Johansen ${ }^{15}$ found that $>70 \%$ of their respondent prefer reading electronically if the text was short, but for longer text (>7-10 pages), their respondents prefer to read it on printed materials. There seems to be a change in the pattern of reading from printed format to digital in the last 10 years. ${ }^{15,16}$ The e-reader's major advantages in clinical education settings are their portability and searchability/userfriendly. $5,7,16$

In addition to the benefits mentioned earlier, the use of ICT in reading and learning also gave several negative impact to their reader. Possible direct negative impact to the reader is to their physical (e.g visual fatigue) and also socialemotional. ${ }^{17,18} \mathrm{~A}$ study by Benedetto et $a l^{17}$ showed us that reading electronically triggered visual fatigue. Based on their study, this group of researcher classified the electronic book readers (e-readers) classification; and it generally refer to two main display technologies: the electronic ink (E-ink) and the liquid crystal display; and the result of their study found out that reading on the LCD (Kindle Fire HD) triggers higher visual fatigue with respect to both the E-ink (Kindle Paperwhite) and the paper book.
Such effects may affect reading interest and preference. ${ }^{19,20}$

Beside that, the multi tasking capabilities of these gadget facilitate its owners to be easily distracted, less patient and lack of focus, socially and emotionally. ${ }^{12-14,18,19}$ Impatience and lack of focus in linear thinking during reading and learning due to multi-tasking habbit might also affect the outcome of their learning activity because it erode their motivation. ${ }^{14,18,19}$ Instead of doing prudent reading to make a better understanding, reading on electronic device then become just a 'nice to know' activity or 'trying to find answer for the questions only, a.s.a.p'. ${ }^{4,5,12}$ When a lecture ask their student a question, the student were rush on to scrolling their touchscreen gadgets, looking for the answer, without feeling the necessary to further elaborate what they read and make a better understanding. Reading become just merely an "answering question activity". Prudent and in-depth reading losing its meaning and also purpose. This might be the reason why it is difficult to find young people today who are still diligent in reading serious big/thick and heavy textbooks. This traditional method of learning seems no longer suitable for those young generation who want full control on every aspect of their live, including learning.

It seems that there is a continous gap between reading and learning, especially for those who read electronically. Internet is actually facilitate reading and learning and further is to encourage the learners to learn more effectively, depend on their own learning style. ${ }^{8,9}$ The term, 'learning style' describes an individual's preferred method of gathering, processing, interpreting, organizing and analyzing information and this differences based on the sensory modalities which are involved in taking in information. ${ }^{8}$ The more sensory organ involved, the more information obtained during learning. ${ }^{8,9} \mathrm{But}$ even with so many advantages of the internet, there are still some obstacle that prevent internet user to go deeper while reading electronically.

\section{SHIFTING TRENDS}

The pride of traditional learning platforms such as reading lectures and textbooks have recently been shifted, supplemented or even changed with reading 
electronically on e-books or article on podcasts and mobile applications; even watching videos of tutorial on clinical or laboratory procedure. ${ }^{3,4}$ This ICT offers more than what traditional printed materials (e.g text-books) can give. The ICT made electronic reader can skip any pre-eliminary/introduction information and goes directly to the part what they want to know; and this can be done in a matter of mili-second, faster than the time needed to turn back the page of your text book and search manually. ${ }^{5}$ It also provide electronic reader the ability to detect, screen and pin-point the area of their interest only. ${ }^{12}$ Learning has shifted from material-centris on to reader/learner-centris thanks to ICT.

In the field of medical education, no medical students seems to bring heavy-printed text-books anymore, because all turn their attention to their gadget for an instant electronic solution to every aspect of what they want to know. The millennial learner who embraces these modern learning platforms is usually also active-users of popular social media, e.g Line, Path, Facebook and Twitter; and with this kind of platform they are more likely to be connected and engaged to each other. This phenomenon actually happened, and in order to accommodate that, a number of medical/biomedic scientific organizations have made their link on social media (e.g Facebook) to facilitate its members for more convenience methods of interaction. Some organization even goes further; they made guideline on the use of social media for medical professionals, for freely sharing recent update and latest advance of information/technology. ${ }^{5}$ This action showed us that ICT actually supports and facilitates continuing medical education for the medical professionals, and also learner like medical students can gain huge benefit from that, e.g in the design and implementation of a social media based platform for the discussion of certain medical topics. ${ }^{16,17}$

\section{POSITIVE IMPACT OF ELECTRONIC READING BEHAVIOUR}

Nowadays, we are still faced with many of great challenges in medicine; from the basic theory into practice; including in almost every aspect of medical education and its environment with also good practice of medicine. During the last century (20th century) all of those mentioned before has shifted forward due to advances in many area of basic sciences (e.g physics, biology and chemistry), with also raising demands for higher standards of health care/health services. All of these information (on achievement and even failure) were made open to public by scientific publication; so everyone can read and learn. This accesability is one of postive impact of e-reading. ${ }^{1}$

This scientific publication were done at least in two way, the first is by printing it traditionally on paper (e.g books) and the second (which now is more popular) is by publishing it electronically; and in the last twenty years, advance and dynamic development of ICT have increased the efficiency of reading and perhaps promoted learning by the implementation of evidence-based practice not just via (1) static-visual (reading) but also via (2) dynamic-visual (watching tutorial on gadget); and even ICT facilitates (3) real-time interaction/ interactive (via electronic chat with lecturers, instructors, experts or other learner). Social media platforms provide a powerful way to integrate medical education in a more global setting. ${ }^{1,11,12}$

Beside that, other positive impact of electronic reading is that because everything about information in the internet is so open and nothing can be hide, the possibility for failure due to reading 'rotten material' has reduced enormously; because this openness allow people to control and look after each other and actually there is no room for 'intentional' mistake. ${ }^{5}$ But still, reading from an electronic source must be done carefully all the time because the information on the internet is so huge, and if the source is not scientifically legitimate, learner should avoid this source immediately.

\section{POSSIBLE NEGATIVE IMPACT}

Internet-based technologies have become part of our daily lives and dramatically changed the interaction between students, lecturers, doctors, physicians-in-training, educators and the world of knowledge. ICT offer new challenges and opportunities for their users (in a positive perspective), but on contrary, it also bring several possible negative impact ${ }^{13,20,21}$

The first possible negative impact is the potency of the making electronic/digital learner become "dull 
learner" or "numb learner" or "superficial/shallow" learner. ${ }^{21}$ Learning from electronic sources, with all the easiness offered, made its active reader/users feel very comfort and graetly facilitated because this easiness in searching any topics is guarantee (with the tagline "personalized"/ "easy to use"/"user friendly"). According to dictionary, numb means 'deprive of feeling or responsiveness' while dull means 'lacking of interest or excitement'; in the context of e-learner from our point of view, both words indicating that there is a decline of interest/ curiosity to learn new things that results as lack of willingness to learn and in the chronic future state might look as dullness of affects. Not to mention that, all the certainty of this convenience in reading digitally while surfing through the internet would cause its users to be too comfortable and do not want to try to dig deeper because of the fast feeling of complacency obtained. In our opinion, this may be the underlying reason why this internet generation has become superficial/shallow learner. ${ }^{20}$

Beginner usually become "numb" or "dull" right away because of this easiness; they refuse to try to go deeper, they easily feel satisfied because with only one click on a button, they get what they want, super-fast and super-easy. This then will shallow their curiosity until reaching the level of very superficial; and they now become supercial/shallow learner. They will not bother to try to find the reason, just reading in parts, because all of the answer for the question can easily get in a matter of millisecond. $^{7}$

Other reason why electronic reader refuses to go deeper because there are so many information avalaible in the internet, and there is potency of become "information overload" syndrome or "infobesity" or " too much information" syndrome; this overwhelming number of information might be difficult to be screen and decipher for unexperienced begginer. All of this will produced a dregdeful and un-integrated knowledge with poor understanding about what they read. ${ }^{17}$

Beside that, actively connected to social media or the internet via gadgets means that there is a huge "potency of being distracted" due to receiving constant notification on chat report, text massage, emails and even phone calls; there is always an urgency to check the gadgets and these mean constant interrupting. ${ }^{13,14}$ Students that learnt using their gadgets actively will potentially become "easily distracted doctors" in the future. Further, this might affect their ideas of making "doctor-patient" contact. In general opinion, until nowadays, the doctors were expected to make close and warmth contact with their patients. This old-fashioned methods has been deeply embedded in the thoughts and expectations of society about a good doctor. The current fear for potential doctors coming from this generation of youtubers is possible distraction to their focus, from focusing on the patient only (patient centered) to focus more of their gadget (gadget centered). They might be more interested in checking updates on their gadgets or phone cells rather than having conversation or interact with their patients. This condition becomes a challenge and a threat to the making of future, well-behaved doctor.

\section{WHAT SHOULD WE DO?}

Improvement on ICT is a blessing but in the same time also a challenge, especially in reading and learning. Both have their own consequences. Eventhough it is difficult to measure the exact impact of ICT on reading or learning in medical education, but still we can see how this changed our life. It is almost imposible to try to prevent interaction between ICT and our life, including medical education. The dynamic of ICT, its expansion and development, also affect our dynamic life.

We notice some possible negative impact of reading from electronic source. For us, this is more a challenge than an obstacle. In a more positive perspective, what was potentially negative (described before) actually can be handled and fixed. The potency of "shallowness/superficial" and "dullness" or "numbness" can be tackled by interactive learning rather than personalized learning. ${ }^{20}$ Learning together with a trustworthy peerof group allow each member to interact, express their ideas and getting almost the same conclusion. Control on the content and group-member behaviour can also be tackle via this route.

The potency of distracting actually can be handled via promoting guidelines of user's behavior on social media, gadgets or the internet. Stake holders should become more concern and focus on 
ethical and good behavior issues, especially ethical issues regarding ICT, including the patient confidentiality, doctor-patient relationship and medical professions professionalism. This issues in ethics topics are rasied everyone's concern, especially in the ICT era.

Beyond than just to simply absorbing everything they read and learn, medical students during their education period should become a more insightful history-taker, keen observers and compassionate physicians who handle their patient as he/she want to be treated. It is obvious that social media can support reading and learning in medical education. But we must also keep in our mind that, eventhough with all the sophistication and convenience that can be offered by the internet/computer, but still computer cannot take everything from our life; there is still plenty of humanity aspect that can only be done by human.

All of the important feature of the internet, e.g connectivity, user-friendly, multi-tasking, interactivity should be able to support reading and learning should be used and maximized to encourage and explore the learning potential of its users. All of those features mentioned before should not make a user-centric condition but instead with these features, connection and networking should be facilitated and maximized, in order to support reading activity and learning. Learning in the digital era, where ICT is inevitability, should be a blessing for their user, especially for the millenial generation.

\section{CONCLUSION}

Internet, social media and personal gadget can make our life easier, including in the context of learning. Development of ICT supports many aspect of our life positively, even so, that to some extent it might caused also some possible negative impact. Responding to it wisely will surely make us all gain benefit from this ICT advancement.

\section{REFERENCE}

1. Dogruer N, Eyyam R, Menevis I. The use of the internet for educational purposes. Procedia Social and Behavioral Sciences. 2011; 28:606-11
2. Jabr F. The Reading Brain in the Digital Age: The Science of Paper versus Screens. Scientific American. Apr 11, 2013. Downloaded from https:/ /www.scientificamerican.com/article/readingpaper-screens/

3. Myrberg C, Wiberg N. Screen vs paper: what is the difference for reading and learning? Insight. 2015; 28(2):49-54

4. Rockinson-Szapkiw AJ, Courduff J, Carter K, Bennett D. Electronic versus traditional print textbooks: a comparison study on the influence of university students' learning. Computers \& Educations. 2013; 63:259-66

5. Evans D. the internet of things: how the next evolution of the internet is changing everything. CISCO ISBG white paper. 2011

6. Poltronieri E, Bravo E, Curti M, Ferri M, Mancini C. Open access publishing trend analysis: statistics beyond the perception. Information Research. 2016; 21(2)

7. Brandstrom C. Using the internet in educationstrengths and weakness- a qualitative study of teachers' opinions on the use of the internet in planning and instruction. Thesis. Akademin for utbildning och ekonomi Avdelningen for humaniora. 2011

8. Kharb P, Samanta PP, Jindal M, Singh V. The learning styles and preferred teaching learning strategies of first year medical students. J Clin Diagn Res. 2013; 7(6):1089-92

9. Shams L, Seitz AR. Benefits of multisensory learning. Trends in cognitive sciences.2008; 30 (10)

10. Proulx MJ, Brown DJ, Pasqualotto A, Meijer P. Multisensory perceptual learning and sensory substitution. Neuroscience and Biobehaviorral Rev. 2014; 41:16-25

11. Freeman S, Eddy SL, McDonough M, Smith MK, Okoroafora N, Jordta $\mathrm{H}$, et al. Active learning increases student performance in science, engineering, and mathematics. PNAS. 2014; 111: 23

12. Ajao POO. Multitasking impact of ICT on learning: case study (LUAS). Thesis. Lahti University of Applied Sciences. 2012 
13. Wallis $\mathrm{C}$. The multi-tasking generation. Time; 2006:22-3

14.Liew J, Chang Y, Kelly L, Yalvac B. (in press). Self regulated and social emotional learning in the multitasking generation. in Sahhuseyinoglu, Ilisko D. How do children learn best.pp 62-70. Ankara Turkey: Children's research center.

15. Aronsen K, Johansen A. Medical students and textbooks as e-books - a survey. Norwegian University of Science and technology. Presented at EAHIL 2016; Seville, Spain.

16. Buzzeto-More N, Sweat-Guy R, Elobaid M. Reading in A Digital Age: e-Books Are Students Ready For This Learning Object?. Interdisciplinary Journal of Knowledge and Learning Objects. 2007; 3: 239-49
17. Benedetto S, Drai-Zerbib V, Pedrotti M, Tissier G, Baccino T (2013) E-Readers and Visual Fatigue. PLoS ONE 8(12): e83676. doi:10.1371/ journal.pone. 0083676

18. Turner AR. Generation Z: Technology's Potential Impact in Social Interest of Contemporary Youth. Thesis. 2013. The Faculty of the Adler Graduate School

19. Chen Q, Yan Z. Does multitasking with mobile phones affect learning? A review. Computers in Human Behavior. 2016;54: 34e42

20. Bennet A, Bennet D. The Depth of knowledge: Surface, Shallow or Deep? VINE. 2008. DOI: 10.1108/03055720810917679 